\title{
The First Authentic Record of the Latham's Snipe Gallinago hardwickii for the Philippines
}

\author{
Yoshimitu Shigeta*, Takashi Hiraoka** and Juan Carlos T. Gonzalez***
}

Key words: Banding, First record, Gallinago hardwickii, Latham's Snipe, Migration, Philippine Islands.

キーワード: 標識調査, 初記録, オオジシギ Gallinago hardwickii, 渡り,フィリピン.

The Latham's Snipe Gallinago hardwickii breeds in southeastern Ussuriland, southern Sakhalin, southern Kuril Islands, Hokkaido, Honshu, and Kyushu during the northern summer and spends the northern winter in New Guinea, Australia and New Zealand (del Hoyo et al. 1996, Higgins \& Davies 1996, Ornithological Society of Japan 2000). It has been suggested that this species migrates directly across the Pacific between the breeding and wintering grounds stopping only on New Guinea Island, because of the scarcity of collecting records from the intervening island chain including the Ryukyu Islands, Taiwan, Philippines, and Molucca Islands (Frith et al. 1977, Higgins \& Davies 1996). Although there were some 70 banding records from the Philippine Islands made during the Migratory Animal Pathological Survey (MAPS) conducted in the late 1960's (McClure \& Leevalis 1972), they lacked supporting evidence such as photographs or specimens. Because of this lack of evidence and the difficulty of distinguishing this species from similar species, especially from the Swinhoe's Snipe G. megala, the MAPS records have not been accepted by later authors (Naarding 1984, 1985, duPont 1971, Dickinson et al . 1991, Kennedy et al. 2000). Other recent field observations reputedly of this species from the Philippines (e.g. Sargeant 1992) also lack conclusive evidence.

During banding work conducted in December 1994 in the Philippines we captured two Latham's Snipe in Candaba Swamp in central Luzon. Here we report on this record, which constitutes the first authentic record of this species for the Philippines, with accompanying photographs. The record not only suggests the possibility of this species migrating through the Philippines, it also raises the possibility that a part of the population of this species may overwinter in these islands.

Candaba Swamp covers an area of 32,000 ha in the Pampanga River Basin in Pampanga and Bulacan Provinces, central Luzon. It is a complex of freshwater ponds, swamps and marshes with surrounding areas of seasonally flooded grassland, arable land and palm savanna on a vast alluvial flood plain (Scott 1989). Banding work in Candaba

\footnotetext{
Received 19 August 2002, Revised 21 October 2002, Accepted 21 October 2002.

* Bird Migration Research Center, Yamashina Institute for Ornithology, Konoyama 115, Abiko, Chiba Pref. 270-1145, Japan.

** Collection Room, Yamashina Institute for Ornithology, Konoyama 115, Abiko, Chiba Pref. 270 1145, Japan.

*** Wildlife Biology Laboratory, Institute of Biological Sciences, College of Arts and Sciences, University of the Philippines at Los Baños, Laguna 4031, Philippines.
} 
Swamp was conducted during 19-21 December 1994 at Bo, Sinipit, Cabiao, Nueva Ecija Prov. $\left(15^{\circ} 15^{\prime} \mathrm{N}, 120^{\circ} 53^{\prime} \mathrm{E}\right)$. Mist nets were set up in the paddy field and wet grassland with tussocks. There were freshwater ponds in the neighborhood. Eighteen mist nets of 61 $\mathrm{mm}$ and $30 \mathrm{~mm}$ meshes in the lengths of the stretched diagonal were used.

The two Latham's Snipe were captured at $5: 00$ a.m. and $6: 30$ a.m. on 20 December. Before release, the birds were given Japan Environment Agency (Kankyocho) bands Nos. 5A-20001 and 6A-12113. At the same time measurements were taken and external morphology was examined. Although we saw Gallinago snipe flush from the ground fairly frequently in the neighborhood of the net site, the two birds were the only Gallinago we captured and we were not sure whether or not other Gallinago snipe were there.

Fig. 1 shows the external morphology of bird No. 5A-20001. The two birds were of the shape and coloration of typical Gallinago snipe with plump body, very long bill, moderately long wings and legs, brownish upper parts and generally whitish under parts.

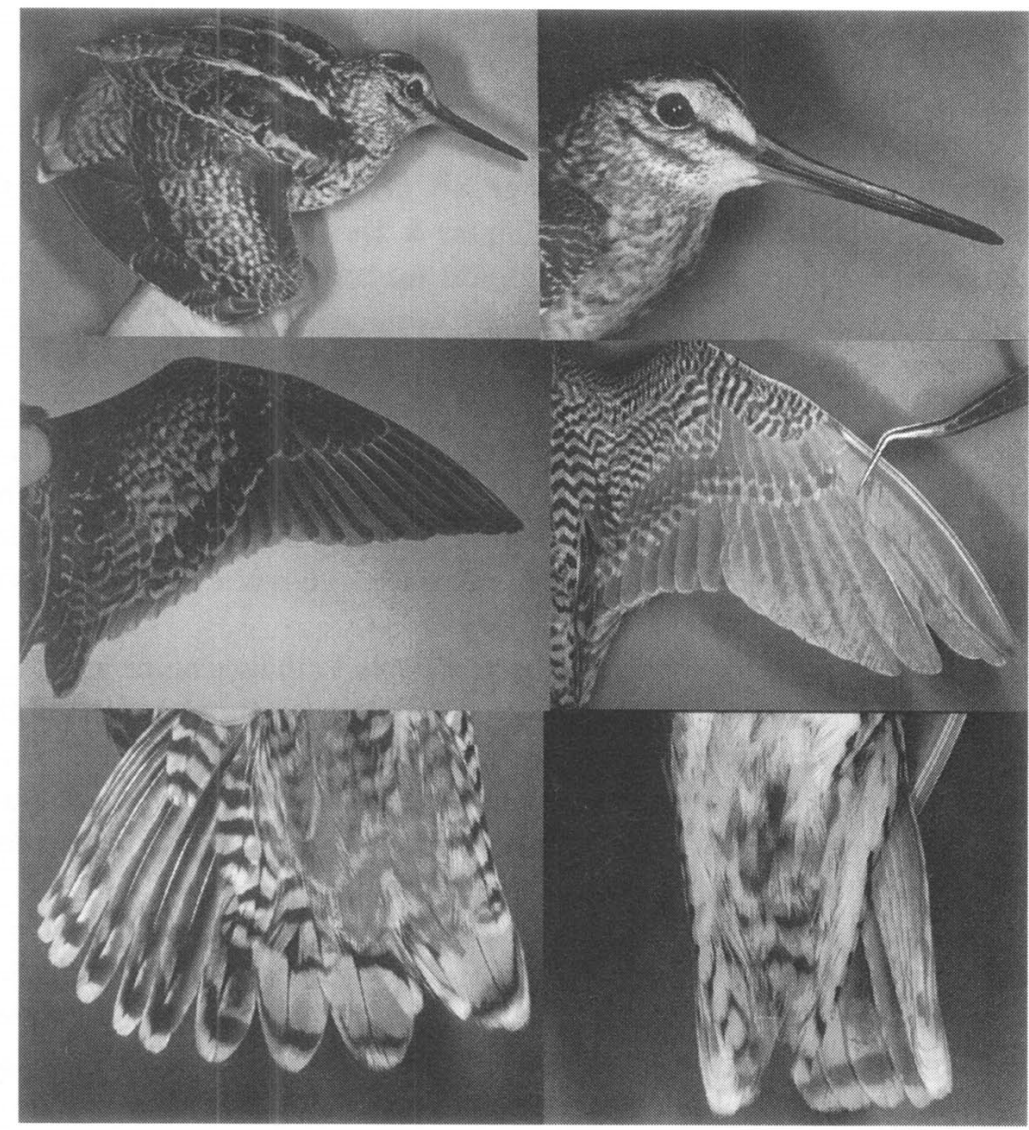

Fig. 1. First winter male of Latham's Snipe Gallinago hardwickii banded at Candaba Swamp, central Luzon, Philippines on 20 December 1994 (Kankyocho band No. 5A-20001). Note that a few worn juvenile median coverts and the worn juvenile tenth primary are retained. 
Table 1. Measurements of the two Latham's Snipe Gallinago hardwickii banded in Candaba Swamp, central Luzon, Philippines on 20 December 1994. Linear measurements are in millimeters and weights are in grams. Measured and weighed by Y. Shigeta.

\begin{tabular}{cccccccccc}
\hline \hline Band No. & Sex/Age & $\begin{array}{c}\text { Max. } \\
\text { wing }\end{array}$ & Tail & Tarsus & $\begin{array}{c}\text { Exp. } \\
\text { culmen }\end{array}$ & $\begin{array}{c}\text { Total } \\
\text { head }\end{array}$ & $\begin{array}{c}\text { Total } \\
\text { length }\end{array}$ & $\begin{array}{c}\text { Wing } \\
\text { span }\end{array}$ & $\begin{array}{c}\text { Body } \\
\text { weigh }\end{array}$ \\
\hline 5A-20001 & \multirow{\sigma}{*}{ 万/1st Winter } & 138.6 & 54.1 & 33.5 & 57.7 & 87.9 & 258.0 & 441.0 & 128 \\
6A-12113 & $\sigma^{7}$ ?/1st Winter & 153.0 & 60.1 & 38.4 & 68.0 & 97.6 & 280.0 & 475.0 & 147 \\
\hline
\end{tabular}

The upperparts were vermiculated with dark brown, light brown, and yellowish white. The head had a dark crown with a light median stripe, a dark eye-stripe, and a dark cheek stripe. The wing was without a thick white bar at the trailing edge of the secondaries and the underwing coverts were heavily barred without any pure white areas. Both birds had 18 rectrices with $\mathrm{T} 1$ to $\mathrm{T} 3$ broad and straight and $\mathrm{T} 4$ to $\mathrm{T} 9$ narrower and gradually shortening towards the outermost rectrix. Both birds were in first winter plumage, retaining the worn juvenile tenth primary and a few worn juvenile median coverts. Measurements are given in Table 1. Since the lengths of wing, tail, exposed culmen, and tarsus of No. 5A-20001 were rather short and the body weight was very light, the bird was considered as a male on a basis of measurements and weights given in Higgins \& Davies (1996). The measurements and body weight of No. 6A-12113 were also within the range of males but the bird can be a female (cf. Higgins \& Davies 1996).

The number of rectrices, other morphological features and measurements show that the two birds we captured were without doubt Latham's Snipe. The Common Snipe Gallinago gallinago, Pintail Snipe G. stenura, and Swinhoe's Snipe G. megala have 14, 26, and 20-22 rectrices, respectively, against 18 in G. hardwickii (Prater et al. 1977). In addition, the Common Snipe differs from the two birds banded in having a thick white trailing edge to the secondaries and pure white parts in the underwing coverts. The Pintail Snipe differs from the birds banded in having much narrower outermost rectrices. The Swinhoe's Snipe has uniformly dark outermost rectrices with white tips, whereas the birds banded had distinctly barred outermost rectrices.

The present banding record shows that at least some Latham's Snipe migrate through the Philippines. Furthermore, the fact that the birds were captured as late as December suggests that they may winter there. One of the reasons Naarding (1985) considered the MAPS records from the Philippines unreliable was that they "took place outside the migration periods of Latham's Snipe." But this is obviously not the case and at least some of the MAPS records might well have been the Latham's.

There have been a few records of the Latham's Snipe from the Ryukyu Islands, Daito Islands and Taiwan, which lie somewhat between the breeding grounds and the Philippines. A Latham's Snipe was banded on 22 September 1979 (Band No. 050-13623) and another on 13 September 1980 (No. 050-15721) at the paddy field near Gabusoka (26 $37^{\prime}$ N, $128^{\circ} 00^{\prime}$ E), Nago City, Okinawa Prefecture, Ryukyu Islands (Yamashina Institute for Ornithology 1980, 1981; T. Mano pers. comm.). Both birds were unsexed and aged as first winter. There are two specimen records from Minami-daito I., Daito (Borodinno) Is., one collected on 17 November 1936 and the other in February 1928 (Hachisuka \& Udagawa 
1953). An adult Latham's Snipe was collected by Robert Swinhoe in Taiwan (Sharpe 1896) and Sugimoto (1938) reported on Trombidiid larvae obtained from a Latham's Snipe collected on 15 April 1937 in Taipei Prefecture. There are six banding records by the banding team of Tunghai University during the MAPS program at Hengchung, southern Taiwan on 10 and 11 September 1969 (McClure 1970, Kobayashi \& Cho 1981).

These sporadic records from the Ryukyu Islands, Daito Islands and Taiwan, along with the banding records reported herein and those of the MAPS program in the Philippines, indicate that there may be more individuals of this species migrating through these islands than previously thought. More field work by ornithologists well trained in identification of Gallinago snipe is needed, however, to determine whether or not this species occurs regularly in migratory and wintering periods in the Ryukyu Islands, Taiwan, Philippines, and Moluccas.

The present study has presented further evidence for the international importance of Candaba Swamp as a migratory bird habitat. We argue that more ornithological research be conducted in the area and conservation measures be taken accordingly to protect this internationally important bird habitat.

We would like to thank Carlo C. Custodio, Marlyn M. Mendoza, Edgardo B. Cañete, Homer I. Gonzales, and Maria Fe L. Portigo of Department of Environment of Natural Resources of the Philippines for their help in the preparation for this cooperative study and in the field work. Andres T. L. Dans of Wildlife Biology Laboratory, UPLB, Amane Mitamura of Yamashina Institute for Ornithology, Satoshi Sasamori and Mitsuru Saito of the Japan Overseas Cooperation Volunteers, Yasuyuki Yamaguchi, Yoshiyuki Obata of the Japanese Bird Banding Association and students of the Wildlife Biology Laboratory, UPLB assisted the field work. Toru Mano kindly gave us the details of his records from the Ryukyu Islands. Stephen Donellan of the South Australian Museum and Chen Cilon of Kyoto University helped in the literature search. Clive Minton assisted with comments on the draft paper and in improving the English. This study was conducted as part of the Cooperative Research on Migratory Avifauna and Bird Banding in Japan and the Philippines funded by the Ministry of Education (currently Ministry of Education and Science) of Japan.

\section{References}

del Hoyo, J., Elliott, A. \& Sargatal, J. (eds.) 1996. Handbook of the Birds of the World. Vol. 3. Lynx Edicions, Barcelona.

Dickinson, E. C., Kennedy, R. S. \& Parkes, K. C., 1991. The Birds of the Philippines. An Annotated Check-list. British Ornithologist's Union, Tring.

du Pont, J. E. 1971. Philippine Birds. Delaware Museum of Natural History, Greenville, Delaware.

Frith, H. J., Crome, F. H. J. \& Brown, B. K. 1977. Aspects of the Biology of the Japanese Snipe Gallinago hardwickii. Australian Journal of Ecology 2: 341-368.

Hachisuka, M. \& Udagawa, T. 1953. Contribution to the Ornithology of the Ryukyu Islands. Quarterly Journal of Taiwan Museum 6(3 \& 4): 141-236.

Higgins, P. J. \& Davies, S. J. J. F. (eds.) 1996. Handbook of Australian, New Zealand, \& Antarctic Birds. Vol. 3. Oxford University Press, Oxford.

Kennedy, R. S., Gonzales, P. C., Dickinson, E. C., Miranda, Jr., H. C. \& Fisher, T. H. 2000. A Guide to the Birds of the Philippines. Oxford University Press, Oxford. 
Kobayashi, K. \& Cho, H. 1981. Birds of Taiwan. Maeda Graphic Arts, Kyoto (in Japanese).

McClure, H. E. 1970. Migratory Animal Pathological Survey, Annual Progress Report 1969. Applied Scientific Research Coorperation of Thailand, Bang Khen, Bangkok.

McClure, H. E. \& Leevalis, P. 1972. Birds Banded in Asia during the MAPS Program, by Locality, from 1963 through 1971. U. S. Army Research Development Group Far East, APO, San Francisco.

Naarding, J. A. 1984. Latham's Snipe (Gallinago hardwickii) in Australia \& Japan. Wildlife Division Technical Report, '84/1.

Naarding, J. A. 1985. Latham's Snipe (Gallinago hardwickii) in Australia \& Japan. Wildlife Division Technical Report, '85/2.

Ornithological Society of Japan, 2000. Check-list of Japanese Birds. 6th revised ed. OSJ, Obihiro.

Prater, T., Marchant, J. \& Vuorinen, J. 1977. Guide to the Identification and Ageing of Holarctic Waders. British Trust for Ornithology Field Guide 17. British Trust for Ornithology, Tring.

Sargeant, D. E. 1992. The Philippines, A Birders Guide to the Philippines. Published by the author, Norfolk.

Scott, D. A. (ed.) 1989. A Directory of Asian Wetlands. IUCN, Gland, Switzerland.

Sharpe, B. 1896. Catalogue of Limicolae in the Collection of the British Museum Catalogue of Birds. Vol. 24. British Museum (Natural History), London.

Sugimoto, M. 1938. Formosan Trombidiid Larvae. Part II. With Description of a New Species. Journal of the Society of Tropical Agriculture 10: 94-98.

Yamashina Institute for Ornithology 1980. Report of the Bird Migration Research Center (February 1, 1979January 31, 1980). Yamashina Institute for Ornithology, Shibuya.

Yamashina Institute for Ornithology 1980. Report of the Bird Migration Research Center (February 1, 1980 January 31, 1981). Yamashina Institute for Ornithology, Shibuya.

\section{フィリピンでのオオジシギ Gallinago hardwickii の確実な初記録}

オオジシギは南西ウスリ一地方, サハリン南部, 千島列島南部, 北海道, 本州, 九州で繁殖 し, 北半球の冬はニューギニア，オーストラリア，ニュージーランドに渡る。本種は, 琉球列 島，台湾，フィリピンなどからの記録がほとんどないことから，繁殖地からこれらの島嶼を経 由せず太平洋を綐断して直接越冬地に渡るとされてきた。フィリピンでは 1960 年代後半に約 70 例の標識記録があるが, 写真などの証拠がないこと, 識別の難しいこと等を理由にフィリピ ン産鳥類として認められていない。我々は，ルソン島中部のカンダバ湿地でおこなった標識調 査で, 1994 年 12 月 20 日に 2 羽の本種を捕獲し, それぞれ環境庁足環 5A-20001 と6A-12113を 装着して放鳥した。これらの 2 羽は, 测定值および外部形態, ことに尾羽の枚数 (18 枚) と形 状から確実にオオジシギであり，フィリピンからの本種の証拠写真を伴う確実な初記録となっ た。この記録により 1960 年代の約 70 例の標識記録むすべてが誤認ではない可能性が出てき た。そして, 琉球列島・台湾などでの捕獲記録があることを考えあわせると, 従来主張されて きた太平洋をノンストップで渡るという説む見直しの必要がある。捕獲時期が 12 月と遅いこ とから, 本種の個体群の一部がフィリピンで越冬している可能性あある。

茂田良光：山階鳥類研究所標識研究室. 干270-1145 千葉県我孫子市高野山 115.

平岡 考：山階鳥類研究所資料室. 干270-1145 千葉県我孫子市高野山 115.

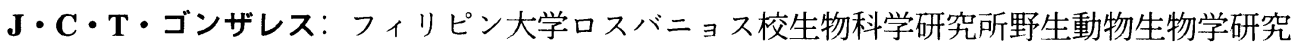

室. Laguna 4031, Philippines. 